Irina Moira Cavaion

School Institute "Iqbal Masih"

Trieste, Italy
UDC $371.3:: 811.163 .6 ' 243(450.361)$

DOI https://doi.org/10.18485/fid.2017.7.ch6

\title{
PROMOTING MINORITY LANGUAGE LEARNING WITHIN MAINSTREAM PRIMARY SCHOOLS: A FIVE-STEP CONSTRUCTIVIST AND IT-ENHANCED MODEL
}

\begin{abstract}
Овај прилог има за циљ да илуструје модел за увођење учења словеначког као мањинског језика у редовно италијанско основно формално образовање (ученици узраста 8-10 година) на један иновативан начин, а које се заснива на принципу да учење мањинског језика није само право његових говорника, већ је и потенцијални ресурс за говорнике већинског језика. Контекст представља италијанска гранична област, а посебно град Трст, где настава словеначког као мањинског језика и даље представља редак и „неопремљен“ пример наставе језика. Наш модел, развијен у периоду од пет година наставе, бави се учењем мањинског језика кроз пет корака који узимају у обзир искуства ученика и наставника у вези са лингвистиком, културом, идентитетом и афективним везама. То је интердисциплинарни и мултисензорни приступ, подржан коришћењем информационих технологија (углавном кроз коришћење интерактивне табле и софтвера за синтезу гласа), за који је тестирана организациона и методолошка изводљивост. Високо конструктивистички алати су предложени као језички портфолио.
\end{abstract}

Кључне речи: настава словеначког језика, настава и учење мањинског језика, конструктивистички приступ настави језика.

\section{Introduction}

This paper aims to demonstrate how the introduction of an effective teaching model for Slovene language into mainstream Italian primary schools can contribute to the forging of a multilingual society in extraordinary ways. Through this contribution, we hope to somehow confirm what Gurt Gorter said in his illuminating plenary speech to this conference (Minority Languages and Multilingualism: in school, at work and in public space) when he described the potentialities of multilingual speakers and indicated them to be capable of both adapting and shaping the social context. He also spoke about responsibility; that is to say, the need to shift from welfare principled actions towards those driven by civil society, 
which in our opinion, can take place only through authentic and mature contact between minority and majority communities and through effective interventions within mainstream school communities.

Minority language learning and teaching within mainstream primary schools, if well exploited, represents a powerful instrument that is capable of laying the foundations of a linguistically and interculturally more aware society. From a didactic viewpoint, it permits an opportunity to develop an integrated, constructivist language learning and teaching approach, where pupils and teachers are jointly engaged in the co-construction of the meaning that all the languages of their linguistic repertoire hold for them as inhabitants of that specific territory (including immigrant pupils). We believe that it is worth challenging the simplistic interpretations (linguistic and cultural) of society promoted by primary schools, a criticism of the education system that was rightly expressed by Gorter in his speech.

It is also our opinion that introducing the Slovene language into Italian mainstream primary formal education could even trigger minority language revival, thereby increasing the level of self-confidence of its native speakers, inspiring the Slovene minority community to participate in a social change with what Klatt (2013) and Malloy et al. (2008) defined as special competencies, linked to their knowledge of both countries' languages and culture and removing possible fears of losing the specific minority identity in an integrated, transnational, cross-border region. Consequently, this could improve relations between minority and majority communities, thus helping to equip mainstream school communities with both sensitive and effective tools with which to correctly approach their minority language counterparts.

\section{The teaching of minority/national minority languages in mainstream schools (in the Friuli Venezia Giulia region and Italy)}

The context of the analysis is the city of Trieste, where the teaching of Slovene as a minority language is supposed to be reinforced by national, regional and international laws that support its formal introduction into mainstream schools. 
However, a very complex sociolinguistic context still makes Slovene a neglected language within Italian mainstream primary education. Slovene in Italy is what Cavaion (2015a:11) calls a "multiple identity border language". Slovene in fact is not (only) a regional minority language but a national minority; a community within a homeland whose members maintain links with people who reside in the neighbouring nation despite having been separated, often for historical reasons. Slovene is also what we (and Europe, see further) call a neighbouring language - the mainstream language of the neighbouring Republic of Slovenia.

Slovene - although protected firstly as a national minority and then as a regional minority language - definitely bears the burden of its status as a national minority, it is a language suffering from "stigmatisation, assuming the silent, inexplicable role of "unfaithful" language" of the former neighbouring enemy country, as claimed in Cavaion (2015a:9). It is also impacted by the ineffective language politics regarding both minority language and neighbouring language teaching in Italy.

The teaching of minority languages in Italian mainstream schools is in fact, not governed by any compulsory regulations, but only by policies left to the discretion of each single school. According to a report commissioned by the Ministry of Education in 2010, which analyses the impact of the law for the protection of minority languages in Italy (Law No. 482/1999), the lack of a national or local language policy to regulate the presence of minority languages in mainstream schools produces detrimental results with regard to minority language prestige. For example, the quality of projects demonstrate a low level of engagement for teaching "the language," whereas efforts only seem to be focused on promoting the cultural aspects of that specific language - far from the European guidelines that refer to "resolute action" for the promotion of minority languages.

On the other hand, the teaching of a neighbouring language in Italy - which has been thoroughly investigated by Cavaion (2015a) - does not apply important European recommendations, such as the Recommendation Rec (2005) 3 of the Committee of Ministers on teaching neighbouring languages in border regions. Nor does Italy consider the enlightening perspectives offered by the paper drafted by Maalouf (2008:16), which re- 
ported the need within Europe to develop "bilateral relations between the peoples of the European countries" by means of "powerful ties based on the knowledge of the language of the other". So far, Italy has no language policies that specifically concern the border regions and its languages. Neither does the region Friuli Venezia Giulia - a multilingual border area with two neighbouring countries, Austria and Slovenia - have specific language policies that would enable the systematic introduction of neighbouring languages into compulsory schooling.

As a result, the official teaching of the Slovene language in mainstream Italian schools in this territory is almost non-existent, with only experimental instances taking place at mainstream primary schools in the provinces of Trieste and Gorizia. The only official teaching of the Slovene language occurs in a few lower secondary schools in the province of Trieste where it is taught as a European Communitarian language - hence, not as a minority or neighbouring language.

Additionally and specifically to the nature of this paper which aims to be a methodological proposal assuming important sociolinguistic views, a specific minority language teaching and learning methodology is missing, which is also derived from the grave absence of courses addressing minority language education within Faculties of Education or professional in-service training courses.

Nevertheless the interest in Slovene language teaching in mainstream primary schools has increased within the province of Trieste in the last 10 years, where almost half ( 7 out of 16 ) of the provincial school institutions have already taken up experimental projects where the Slovene language is taught as a minority language, as described by Cavaion (2015b). Within these schools the interest is still quite high, but financial cuts to the national program for minority languages protection are preventing the continuation of those projects, according to Cavaion (2015b).

On the other hand, new directives from Europe have led to further development within the area of plurilingual education policies. In particular, we make reference to the Guide for the development and implementation of curricula for plurilingual and intercultural education, CoE (2010), where there is an important call for crossover links between "languages as subjects" as the central element in plurilingual, and intercultural education, besides experiential learning and intercultural encounters. 
These ambitious requests clash with a context mostly characterised by mainstream language teachers - in this case teachers of Italian - who perceive and declare themselves to be the only ones capable of planning pupils' linguistic education. They often complain about a shortage of time to complete the whole scheduled program and therefore, perceive themselves not to be in a position to realise crossover links with other linguistic teaching - and even less so with minority language teaching, even though pupils have more unconscious contact with a minority language than any other, which represents an enormous undisclosed treasure.

\section{Need for an ecological approach}

Having taken everything discussed into account, we believe it is time to make sensible and systematic methodological proposals to introduce the Slovene minority language into primary mainstream Italian schools for reasons of social integration, the need to raise intercultural and linguistic awareness, the implementation of school language curricula, and finally for innovation in language teaching. Nevertheless, there is the need for an "ecological approach" - or as Kumaravadivelu (2006:172) would define it a "hermeneutic perspective of situational understanding" - in order to make Slovene minority language teaching in Italian majority language settings possible, as well as effective, desirable and successful. An approach that is respectful and "geared" towards the organisational and financial specificities of the context (feasibility principle); sensitive to the relationships and perceptions the school community hold towards the Slovene language and community (sensitivity principle); follows a constructivist language teaching approach (constructivist principle); and proposes appealing, daring activities (appealing methodology principle) capable of making the Slovene language part of "possible language learning" within the context of neglected language learning.

The model that we have developed and that we hereby present, follows the principle of feasibility that has been adapted to the Italian context of school organisation, where there is a serious lack of financial means to sustain the presence of external specialised staff (specialised minority language teachers, who actually do not exist as a specialised trained 
category). In addition, long-term changes, for example minority language lessons throughout the school year, cannot be considered within a school timetable already suffering from a shortage of time that prevents the implementation of curricular planned programs. For these reasons, we planned a short-term module (for once a week, lasting for a maximum six weeks) with in-service (trained) teachers who possessed the following characteristics: minority language linguistic skills, a strong motivation to teach that language, a cultural awareness and appreciation of that language as a language of the territory and finally, knowledge of language teaching strategies. The modular approach foresees a close collaboration between all class teachers and the member of staff who would teach the minority language in order to make the lessons a shared language experience enriched by interdisciplinary observations and contributions.

Intercultural sensitivity to the context is required so as to be able to intervene wisely, attentively and empathically as far as the sociolinguistic beliefs and experiences of pupils (and colleagues) are concerned. Often, the degree of sensitivity is affected by a limited number of authentic experiences with the Slovene language, misconceptions frequently handed down by former generations, or a lack of awareness of the linguistic and social functions of languages and of the political power of linguistic behaviours.

From a didactical viewpoint, a constructivist approach seems to be the most suitable, where learning the minority language, both as a symbolic object and as an expressive and communicative means of understanding the territory and its people, assumes the meaning and shape of a shared journey that unites pupils and teachers through their desire to discover rather than through "traditional" learning and teaching techniques. In a sense, the disclosure of language becomes the very aim of the entire undertaking. During our lessons, children were asked to define what the Slovene language meant to them. They responded that it did not represent a foreign language, but on the contrary, is known to them through friends and relatives, through reading and listening in their everyday environment, and therefore, is a language that is part of their daily lives.

Posters that record the process in order to make it visible; a Slovene language portfolio that collects the learning paths, content and experiences of those involved; teachers who are well-disposed to share and comment 
upon the difficulties encountered by pupils and themselves when dealing with the specificities of the language, as well as prompt spontaneous and contrastive analysis, are a few key aspects of a teaching approach based on the principle that linguistic learning must be a co-construction of knowledge and not merely a short experience of immersive language learning, where a native speaker comes and goes with his/her language.

All these aspects must be presented by means of an appealing methodology, capable of triggering children's natural curiosity about linguistic diversity and dispelling possible misconceptions. Finally, the methodology is useful in helping to elicit individual and collective knowledge, which throughout the years has proven to be quite substantial as a means to motivate children and colleagues to actively take up this short linguistic journey; a journey that will allow them to have an enriched view of the linguistic and cultural background of their geographic environment. In addition, they will be encouraged to recognise, learn, re-learn words from the Slovene language that are useful, or simply, affectively meaningful in relation to their linguistic needs. We identified an appealing methodology as that which introduces explorative scenarios and daring activities, possibly IT enhanced, that are able to manage, provoke and defuse possible prejudices regarding the language; where children are asked to participate in sound games, act out short role-plays and engage in interactive board activities.

\section{The 5-step model to introduce (and maintain) the Slovene language in Italian mainstream primary schools}

Our model was developed through five years of teaching ten primary school classes at the same school institution (classes in Year 4 and 5; consisting of 200 children aged between eight and ten years old). The classes were characterised by a highly homogeneous linguistic background (none had relatives with Slovene as a mother tongue; and only four or five were from an immigrant background). Nevertheless, justified by a constructivist approach, we believe that classes characterised by a multilingual and multicultural background can only positively contribute to the success of the model in all its steps. Pupils and teachers have been engaged in linguistic, cultural, affective, identity and relationship - related experiences, where 
teachers' experiences with the Slovene language have also been recorded.

The model follows an interdisciplinary and multi-sensory approach, bringing together teachers from various disciplines (mostly with a background in humanities e.g. History and Geography, but also from the Arts e.g. Music, Visual Arts, and Physical Education) according to their knowledge of the language. It is also a technologically enhanced model (mainly through the use of the interactive board and vocal synthesis software).

Its organisational and methodological feasibility has been tested within a school institution, which was assumed to be typically representative of a primary school in the province of Trieste from a sociolinguistic and organisational viewpoint, notwithstanding the very low presence of immigrant children.

The model aims to introduce the study of the Slovene minority language into the final classes of Italian primary schools (Years 4 and 5); to encourage it to be perceived as possible language learning in the first ap-

plication of the model (Year 4); and then to consolidate and raise the level of the linguistic knowledge in the second application (Year 5).

The following five steps constitute the model, which we will describe in detail in the following paragraphs.

STEP 1: awakening-provoking- eliciting

STEP 2: teaching and learning language

STEP 3: playing with sounds

STEP 4: reading my world

STEP 5: reflecting - My Slovene language portfolio

Altogether, the steps add up to a five or six-week module, which is likely to involve one hour per week of interventions carried out possibly - but crucially - by a teacher of the school who has sufficiently mastered the Slovene language (but is not a Slovene mother - tongue speaker), has a good knowledge of language teaching strategies and of cultural aspects related to the Slovene language and community. Foreign language teachers are the strongest candidates, but they could also be teachers of the Italian language. Another determining factor is the contemporary presence of other class teachers for reinforcing the meaning of a language that belongs to the environment and to the everyday lives of all the teachers. Experience 
with the Slovene language, its representatives, its geographical and political environment are at the centre of this approach.

\section{Cavaion 2016 \\ 5-step model}

for introducing Slovene minority language into Italian mainstream schools
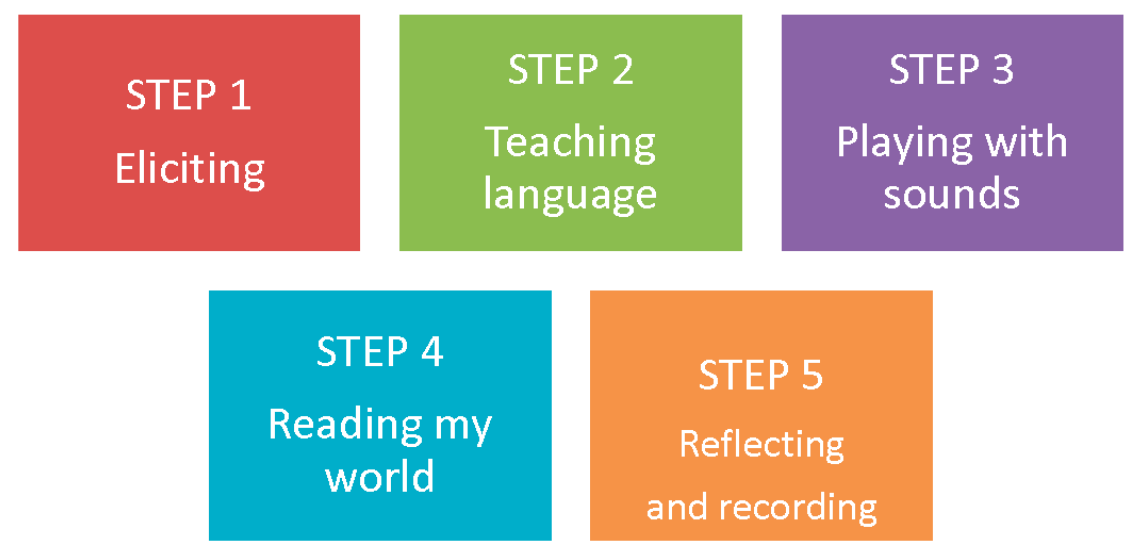

\section{STEP 1: awakening-provoking- eliciting}

We called the first step the " awakening-provoking-eliciting" phase, which involves

3. the "Provoking greetings" activity

4. a brainstorming session: "the Slovene language and me"

Provoking greetings

Here the teacher, who is going to provide the five or six lessons in and about the Slovene language, encourages the pupils through greetings and easy communicative structures in Slovene without having previously informed the children about the lessons. We have noticed how much this kind of approach succeeds to entertain the pupils and facilitate freer communication about the Slovene language, which they usually recognise after a few uttered words. Pupils are often surprised by this as they expect the teacher to talk in Italian or English (which is the only official curricular foreign language taught in lower primary Italian classes). This is the im- 
portant phase which will determine how the Slovene language is admitted into mainstream language learning, because it encourages pupils to participate actively, personally and effectively.

The brainstorming session: "The Slovene language and me"

Encounters with representatives of the Slovene community in Trieste, with people from the neighbouring country of Slovenia itself, or with those who speak "similar languages" (other Slavic languages), as well as other experiences with the Slovene language are usually communicated in a spontaneous and enthusiastic way during this phase. Narratives represent the very first step of the formal encounter with the Slovene language. This phase therefore, brings together pupils and teachers and enables them to engage in something unusual which gives a pleasant sense of "shared experience". All the narratives and words are recorded in posters, either on paper or digital format through the interactive board (flip charts). Posters usually have the following titles:

- Slovene to US

- Words We KNOW

- Slovene We WOUld LiKe to LEARN

In the second application of the model (Year 5), these same activities can be recycled with the aim of eliciting pre-existing knowledge in order to make pupils aware of their improved (or conversely, unimproved) - knowledge of the Slovene language. The posters can record the experiences that pupils (and teachers) already had with the language acquired through the previous application of the model.

\section{STEP 2: teaching and learning language}

The second step is probably the most traditional in the sense that it is similar to an English as a Foreign Language lesson in terms of activities (role plays, dramatizations, songs and plays), which provides pupils with simple and basic communicative structures such as:

- Greetings

- "about me" structures (identity, feelings)

- Courtesy forms (thanks, please)

- Directions (Where's the...?)

- Vocabulary pupils choose to know (colours, numbers, body parts, etc.) 
This second step can last one or two lessons, depending on whether the school decides to apply a five or six-week model. Over the years, we have noticed a surprising capability among the majority of pupils to recall these few communicative structures and vocabulary merely through a single presentation. We have also been impressed by their capacity to repeat words that contain typical Slovene sounds ( $\check{c}, z ̌, \breve{s})$ and which can be considered very different from Italian language sounds. We reached the empirical conclusion that there might be a positive environmental influence that makes it more easy to learn these expressions and sounds.

Naturally, in a second application of the model (Year 5), the content and the structures will be repeated and implemented according to pupils' expressed interests and desires within the initial brainstorming session.

\section{STEP 3: playing with sounds}

The third step, following that which provides communicative structures, includes linguistic games that are all based on sounds. They are:

- isolated pronunciation of sounds (Orchestra of Slovenian sounds)

- their recognition (Show if you have.., Touch the letter)

- pupils' capability to decode them (Match)

- $\quad$ and to read them (Read the word)

- tongue twisters (Say!)

Previously, pupils had usually been provided with flashcards and word cards that they had chosen and displayed when the teacher uttered the sounds/words. Nevertheless, in recent years, flashcards have been substituted with digitally edited versions of the activities listed above (through the recording and embedding into multimedia files supported by the interactive board software). Consequently, this has increased the versatility of activities, thus allowing teachers who have not really mastered the language to engage with more confidence in this delicate step of the model.

It is not surprising to discover that digital materials for this stage of Slovene language learning do not exist and we had to build them all.

We believe this step is quite crucial, because it consolidates the natural inclination of pupils to repeat words and sounds in Slovene following formal presentation for the first time in the previous step - hence the response of pupils becomes more conscious. The pupils' awareness of how the process of language learning develops is one of the basic principles of the model. 


\section{STEP 4: reading my world}

\section{Outside school trips}

In the fourth step, which should be carried out in the fourth or fifth week of the model, pupils are "ready", motivated and aware enough to explore their everyday environment with an improved awareness of their linguistic and cultural background. In an ideal case, we would be able to take classes on a trip outside school, visiting places they already know, but which they know very little about in relation to their connections to Slovene culture: for example, small Slovene villages on the periphery of the town, farms, farm holiday centres, as well as cultural and sports institutions in the town, such as theatres, schools, newspapers and sports halls.

During these trips, pupils sometimes experience a great opportunity to listen to people speaking Slovene and to exchange a few words. In any case, they physically perceive - sometimes for the very first time - the presence of the Slovene language and culture within their territory. Their monolithic perception of the linguistic and cultural environment is now already under discussion.

Virtual journeys: the Digital Units about the Slovenian environment

In cases where we are not able to organise trips out of school, we would take pupils on virtual journeys that we have created through PowerPoint presentations or flipcharts for interactive boards. So far, we have devised digital units about the Carst region and the Slovene institutions of Trieste. It has been noted that interdisciplinary multimedia materials stimulate pupils on many levels and in school subjects, including History, Geography, Citizenship, and the Arts. The design of other materials is in progress.

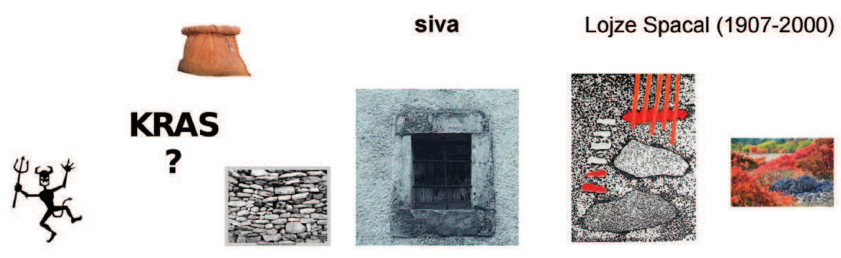

Guess!

A very effective activity at this stage is "Guess!", an interactive digital game where pupils are expected to guess very well-known Slovenian 
tourist or shopping locations through reading their names, which pupils usually read incorrectly, but without any awareness or regard for their mistakes. It represents a sort of final test for the first application of the model. Results are often very satisfactory for teachers and pupils alike, who find themselves able to exclaim: "Now I know how that place sounds!".

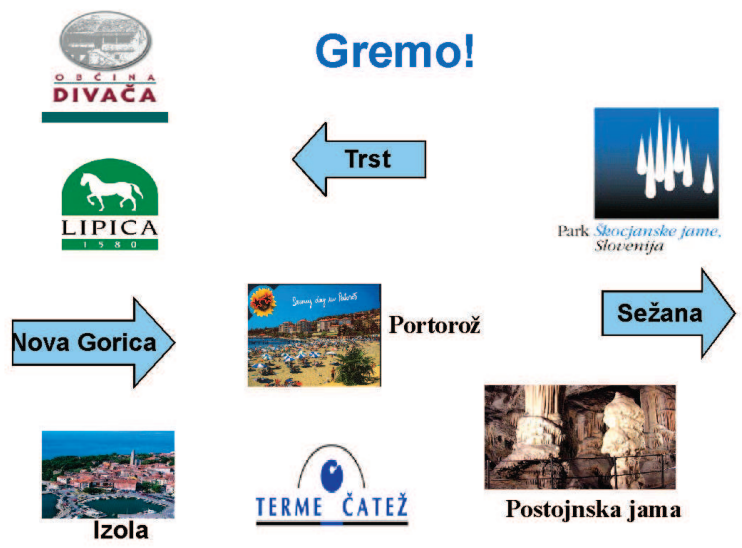

\section{5 STEP: reflecting}

\section{My Slovene language portfolio}

The last step is made up of a highly constructivist learning tool which so far, pupils have loved and exploited to a substantial degree. While they are expected to fill in their personal information for the Slovenian Language Portfolio, it is also where they can find both the linguistic structures and vocabulary they have learned as well as their personal or collective comments on their learning process. In addition, there are also voluntary short essays, usually on the subject of out-of-school trips, that have been completed in collaboration with other teachers. Pupils are always very much surprised by their own thoughts. They like to bring home the language they have learned and their short, but meaningful journey, into the interesting world linked to a so-called minority language. Feedback from parents and even other relatives confirms the success of the five-stepmodel, which produces a concrete outcome in the form of a portfolio that 
they can keep and even exploit in the event that they will take up the Slovene language in lower secondary school. A digital form of the Portfolio is about to be devised.
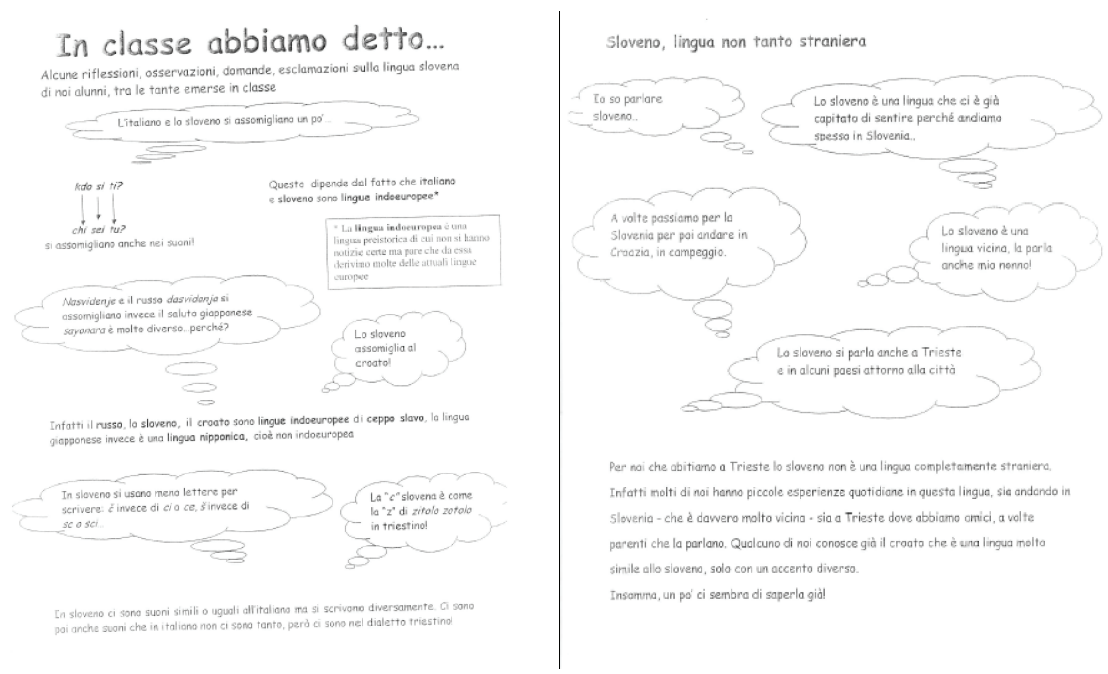

\section{Results and application of the model}

The model, as described above, ideally works if applied with continuity and coherence for classes in Years 4 - 5 of primary school. Results are usually interpreted in the context of the raised cultural, intercultural or linguistic awareness of pupils and teachers who take up the model and of course, possessing an enriched linguistic knowledge of the Slovene language (as we can assume that very few pupils do not know any Slovene words). At the end, pupils are usually able to present themselves in Slovene, carry out rudimentary interaction within a Slovenian environment through appropriate greetings, courtesy forms and simple questions. They are also finally able to correctly pronounce the names of the places where they live.

The model requires a large scale evaluation. Its application in fact, has been limited to only one school institution, although other schools 
within the networking circle of this institute are also interested in applying the model. However, for this to take place, a well-defined local linguistic policy that is open to change is needed in order to support and disseminate such a linguistic intervention in schools. In addition, financial support is needed for teacher training and for the development of material; above all, digital materials which will function both as effective linguistic support to teachers who have not mastered the language to a high degree and as a contribution to the constructivist approach of the model.

\section{Conclusions}

The Slovene language still represents an unequipped and officially neglected form of language learning in mainstream schools within the Italian border province of Trieste. Nevertheless, it has been noted that civil society is increasingly recognising the need to create space within the local compulsory primary school system for the introduction of this language teaching. Accordingly, this trend should be considered by school staff and politicians as an ideal context within which to develop an awareness of language, where a multilingual learning environment can be created through minority language teaching and learning. However, the strategies and teaching materials required for this to take place are missing.

The five-step model that has been described has been demonstrated

over the years to be feasible and effective. If applied and introduced systematically into all the primary schools of the Province, it would act as a springboard for a type of language teaching that is still undervalued, but definitely needed.

\section{References:}

Brezigar, B. (2003). Le lingue meno diffuse nella scuola in Europa. In S. Schiavi Fachin. (Ed.), L'educazione plurilingue: dalla ricerca di base alla pratica didattica (pp.47-58). Udine: Editrice Universitaria Udinese.

Brezigar, B. (2006). La diversità linguistica e culturale: patrimonio comune europeo. In Annali della pubblica istruzione: Le minoranze 
linguistiche in Italia nella prospettiva dell'educazione plrilingue. La legge n.482/1999 sulle minoranze linguistiche nel settore scolastico. Bilancio dei primi sei anni di attuazione (pp.144-151), 5-6/2006. Bologna: Le Monnier.

Cavaion, M. (2015a). Teaching and learning primary neighbouring language through cross-border contacts (unpublished doctoral dissertation). University of Primorska, Koper, Slovenia.

Cavaion, I.M. (2015b). Tante esperienze nella scuola della provincia: presentazione al Convegno per le scuole e la cittadinanza »Lo sloveno per i ragazzi di Trieste«. Trieste, 19 May 2015.

$\mathrm{CoE}$ (2010). Guide for the development and implementation of curricula for plurilingual and intercultural education.

Constitution of Italian Republic, Official Gazette, December 27, 1947, n. 298.

De Mauro, T. (1998). Storia linguistica dell'Italia unita. Roma, Bari: Editori Laterza.

European Charter for Regional or Minority Languages, CETS No: 148. Strasbourg. 5/11/1992 Council of Europe.

Framework Convention for the protection of national minorities and explanatory report, Strasbourg, February 1995 (Doc H. (95) 10).

Gorter, G. (2015). Minority Languages and Multilingualism: in school, at work and in public space. Lecture at the $15^{\text {th }}$ ICML Conference. Belgrade 28-30 May 2015. Faculty of Philology of the University of Belgrade. Serbia. Belgrade, 28 May 2015.

Iannàccaro, G., Dell'Aquila, V. (2011). Historical linguistic minorities: suggestions for classification and typology. International Journal of Sociology of Language, 210, 29-45.

Klatt, M. (2013). National minorities as a model for cross-border integration. Lessonsfrom Schleswig. In J. Beck, B. Wassenberg (Eds.), Grenzüberschreitende Zusammen-arbeit leben und erforschen (Bd.5): Integration und (trans-) regionale Identitäten (pp.301-319). Stuttgart: Franz Steiner.

Maalouf, A. (2008). A rewarding challenge how the multiplicity of languages could strengthen Europe. Proposals from the Group of Intellectuals for Intercultural Dialogue set up at the initiative of the European Commission. Brussels 2008. 
Malloy, T.H. (2010). National Minorities in the 21st Century Europe: new discourses, new narratives? ECMI Issue Brief \#, 24.

Malloy, T.H. et al. (2008). Competence Analysis: National Minorities as a Standortfaktor in the Danish-German border region. Working with each other, for each other. Bozen/Bolzano: Europäische Akademie EURAC Research.

MIUR (2010). Lingue di minoranza a scuola. A dieci anni dalla Legge 482/99. Il plurilinguismo scolastico nelle comunità di minoranza della Repubblica Italiana, Quaderni della Direzione Generale per gli Ordinamenti Scolastici e per 1'Autonomia Scolastica No.1, March 2010.

Recommendation Rec (2005) 3 of the Committee of Ministers to member states on teaching neighbouring teaching language in border regions. Strasbourg: Council of Europe.

Regulations on the Protection of Historical Linguistic Minorities. Law No. 482, of the $15^{\text {th }}$ December 1999.

Regulations on the Protection of Slovene Linguistic Minority in the region of Friuli-Venezia-Giulia. Law No. 38, 23 February 2001.

Serena, O. (2003). La tutela e la valorizzazione della lingua ladino-friulana. I riferimenti normativi. In S. Schiavi Fachin (Ed.), L'educazione plurilingue: dalla ricerca di base alla pratica didattica (pp. 83-96). Udine: Editrice Universitaria Udinese.

\begin{abstract}
This contribution aims to illustrate a model to innovatively introduce the teaching of Slovene as a minority language into mainstream Italian primary formal education (pupils aged 8-10 years old), based on the principle that minority language learning is not only a right of its speakers, but is also a potential resource for the majority language speakers. The context of this intervention is the Italian border region, and specifically the city of Trieste, where the teaching of Slovene as a minority language is still a rare and "unequipped" language teaching activity. Our model, developed over five years of teaching, examines the study of the minority language through a five-step pathway that engages those experiences of pupils and teachers related to linguistics, culture, identity and personal relationships. It is an interdisciplinary and multi-sensory approach, IT-enhanced (mainly through the use of the interactive board and of vocal synthesis software), the
\end{abstract}


organisational and methodological feasibility of which has been tested. Highly constructivist tools are proposed as the language portfolio.

Keywords: Slovene language teaching; minority language teaching and learning; constructivist language teaching approach

\section{Biographical statement}

IRINA MOIRA CAVAION finished her PhD in Plurilingualism and Intercultural Communication Studies at the Faculty of Education of the University of Primorska, Koper in 2015. She works as a primary school English teacher in Trieste, where she also lives, and she is also committed to the teaching of minority and neighbouring languages in mainstream primary schools.

E-mail: irinacavaion@hotmail.com 